'waldenase', causing inversion at $\mathrm{C}_{(3)}$ of the pentose, and resembling that recently suggested as active in Pseudomonas hydrophila

Frank Dickens

D. H. Willitamson

Courtauld Institute of Biochemistry,

Middlesex Hospital Medical School,

London, W.I. July 16.

'Horecker, B. L., Smyrniotis, P. Z., and Seegmiller, J. E., J. Biol. Chem., 193, 383 (1951).

Horecker, B. L., Smyrniotis, P. Z., and Klenow, H., J. Biol. Chem., 205, 661 (1953)

${ }^{3}$ Axelrod, B., and Jang, R., J. Biol. Chem, 209, 847 (1954).

- McGeown, M. G., and Malpress, F. H., Nature, 173, 212 (1954).

'Ashwell, G., and Hickman, J., J. Amer. Chem. Soc., 76, 5888 (1954).

'Ashwell, G., and Hickman, J., J. Amer. Chem. Soc., 77, 1063 (1955)

'Lampen, J. O., J. Biol. Chem., 204, 999 (1953).

s Hochster, R. M., Canad. J. Microbiol., 1, 346 (1955).

\section{Modification of Response to Adrenocortico- trophic Hormone by the Simultaneous Administration of Gonadotrophic Hormones}

MANY facts suggest that the adrenal-gonad relationship is an intimate one ${ }^{1}$. Our previous work ${ }^{2}$ has indicated that the mouse ovary, provided it is in the luteal phase, has an effect similar to that of the adrenal cortex. While appreciating that major species differences may occur, this finding led us to commence experiments on the adrenal-gonad rela. tionship in the guinea pig, since the urinary steroids in this species are excreted in sufficiently large amounts to be determined by routine chemical methods. It has now been shown that the response to adrenocorticotrophic hormone (ACTH) is modified by the simultaneous administration of gonadotrophins.

Ten similar experiments, each using four mature female guinea pigs, were planned as follows :

\begin{tabular}{|c|c|c|}
\hline $\begin{array}{c}\text { Day of } \\
\text { experiment }\end{array}$ & $\begin{array}{l}\text { 'ACTH-only' group. } \\
\text { Guinea pigs } A \text { and } B\end{array}$ & $\begin{array}{c}\text { 'ACTH }+ \text { Gonadotrophin' } \\
\text { group. Guinea pigs } \\
C \text { and } D\end{array}$ \\
\hline $\begin{array}{l}1 \\
2,3 \\
4 \text { to } 15 \\
16,17\end{array}$ & $\begin{array}{l}\text { No treatment } \\
\text { ACTH } \\
\text { No treatment } \\
\text { ACTH }\end{array}$ & $\begin{array}{l}\text { No treatment } \\
\text { ACTH } \\
\text { C.G. }+ \text { P.M.S. } \\
\text { ACTH + C.G. + P.M.S. }\end{array}$ \\
\hline
\end{tabular}

Subcutaneous injections of 10 r.ण. ACTH gel (Armour Laboratories or Wilson Laboratories) twice daily, 50 x.v. pregnant mares' serum gonadotrophin (P.M.S. ; Boots Pure Drug Co., Ltd.) in distilled water once daily, and 50 I.U. chorionic gonadotrophin (C.G.; Organon Laboratories, Ltd.) in distilled water once daily, were given into separate sites. Animals were maintained on a standard diet supplemented by 15 gm. cabbage daily. Gonadotrophin treatment led to extensive ovarian luteinization. 17-Ketosteroids and 17-ketogenic steroids were determined on 24-hr. collections of urine from pairs of animals by the method of Norymberski and others ${ }^{3}$. Urine was collected into flasks containing a few drops of chloroform, and standing in vacuum flasks containing solid carbon dioxide. Burstein, Dorfman and Nadel ${ }^{4}$ have shown that the main corticosteroids in normal guinea pig urine are cortisol and 6 6 -hydroxycortisol.

Results, expressed as the mean excretion of steroid in mgm. \pm S.D./guinea pig/24 hr., are summarized as follows :

\section{Days of experiment 'ACTH-only' group 17-ketosteroids ACTH + gonadotrophin' grou 17-ketosteroid 17-ketogenic steroids}

$$
2,3
$$

16,17

The mean difference in 17-ketosteroid excretion between the first and second periods of ACTH administration was $-0.01 \pm 0.22 \mathrm{mgm}$. for the 'ACTH-only' group, and $-\overline{0.01} \pm 0.29 \mathrm{mgm}$. for the 'ACTH + gonadotrophin' group. These results are not significantly different $(P=0 \cdot 75)$. The mean difference in 17-ketogenic steroid excretion between the first and second periods of administration of adrenocorticotrophic hormone was $-0.01 \pm$ $0.10 \mathrm{mgm}$. for the 'AC'TH-only' group and $-0.26 \pm$ $0.15 \mathrm{mgm}$. for the 'ACTH + gonadotrophin' group. These results are significantly different $(P=0.007)$.

The urinary excretion of 17-ketogenic steroids in response to administered adrenocorticotrophic hormone has therefore been modified by treating the animals with gonadotrophic hormones, and experiments are in progress to try to elucidate this effect. Gonadotrophin treatment did not alter the urinary 17-ketosteroid response to adrenocorticotrophic hormone.

We are indebted to the Medical Research Council for a gift of adrenocorticotrophic hormone.

Department of Chemical Pathology,

Barbara E. Clayton

JOYCE E. HAMMANT

St. Thomas's Hospital Medical School, London, S.E.1.

June 3.

1 Parkes, A. S. Physiol. Rev., 25, 203 (1945). Prunty, F. T. G., and Clayton, B. E., Ciba Colloquia on Endocrinology, 1V, 347 (1952).

' Clayton, B. E., and Prunty, F. T. G., J. Endocrinol., 7, 362 (1951). ${ }^{3}$ Norymberski, J. K., Stubbs, R. D., and West, H. F., Lancet, i, 1276 (1953). Głbson, G., and Norymberski, J. K., Ann. Rheunatic Dis., 13, 59 (1954).

' Burstein, S., Dorfman, R. J., and Nader, E. M., J. Biol. Chem., 213 , 597 (1955).

\section{Separation of Ehrlich Ascites Tumour Cells from Other Cellular Elements}

THe experimental production of ascites tumours has offered an ideal material for biological, physiological and biochemical research on neoplastic cells ${ }^{1}$. For many problems, however, the variable admixture of leucocytes and other contaminating host cells in the ascites tumours (cf. ref. 1) implies a source of orror which in certain cases may be of great importance. We have therefore investigated the possibility of reducing the concentration of such cells with the aid of a counter-streaming centrifuge, the prineiple of which has already been described by one of us (P. E. L.) $)^{2}$. In this centrifuge, constructed mainly for the separation of differently sized particles of the same specific density, liquid containing the particles to be separated is forced to stream through a conical centrifuge tube against the centrifugal force. Here the bigger particles down to a required size are concentrated (fraction $M$ ), whereas the smaller ones are carried off by the continuous stream of liquid to a second tube of a different shape where they are made to sediment (fraction $G$ ).

The tetraploid line of the Ehrlich ascites tumour ${ }^{1}$ was used for the experiments. Cell samples were withdrawn from the peritoneal cavity at various intervals after inoculation. They were diluted with Krebs's phosphate Ringer solution, containing 1 per 